\title{
The Phenomenon of Online Islamic Boarding School Learning in the Era of the Covid-19 Pandemic
}

\author{
Rudy Al Hana \\ UIN Sunan Ampel Surabaya \\ rudy.alhana@uinsby.ac.id \\ Dian Aulia Nengrum \\ UIN Sunan Kalijaga Yogyakarta \\ dianaulianengrum@gmail.com
}

\author{
M. Yusuf \\ UIN Sunan Ampel Surabaya \\ yusuf.much21@gmail.com
}

\begin{abstract}
The Covid-19 pandemic which spread rapidly resulted in Islamic boarding schools closing teaching and learning activities, one of which was the Darullughah Wadda'wah Bangil Islamic Boarding School. In an effort to break the chain of the virus, Asatidz urged students to "stay safe," "stay home" and "stay dars." The appeal to "keep learning" is done online via Dalwa TV with a predetermined schedule. However, long before the pandemic, Darullughab Wadda'wah Islamic Boarding School was already actively conducting online studies via YouTube under the account name "Dalwa Tv." This is none other than because the Darullughab Wadda'wah Islamic Boarding School is able to transform quickly. In addition, so that the alumni and guardians of students can take part in the studies conducted at the pesantren. This is evidence of the seriousness of the pesantren in educating students with an adequate education system, even though the students are not muqim in the pesantren. Especially the alumni and lovers of Darullughah Wadda'wah Islamic Boarding School.
\end{abstract}

Keywords: Ta'lim online, The Covid-19 Pandemic, Darullughah Wadda'wah

\begin{abstract}
Abstrak: Pandemi Covid-19 yang menyebar dengan cepat mengakibatkan pondok pesantren meliburkan kegiatan belajar mengajar, salah satunya ialah Pondok Pesantren Darullughah Wadda'wah Bangil. Dalam upaya memutus mata rantai virus, asatidz menghimbau para santri agar "stay safe," "stay home" dan "stay dars." Himbauan "tetap belajar" ini dilakukan secara online via Dalwa TV dengan jadwal yang sudah ditentukan. Namun jauh sebelum pandemi, Pesantren Darullughah Wadda'wah sudah aktif melakukan kajian online via youtube dengan nama akun "Dalwa Tv." Hal ini tidak lain karena memang Pondok Pesantren Darullughah Wadda'wah mampu bertransformasi dengan cepat. Selain itu, agar para alumni dan wali santri dapat mengikuti kajian yang dilakukan di Pesantren. Hal ini menjadi bukti keseriusan lembaga pesantren dalam mendidik para santri dengan sistem pendidikan yang memadai, meskipun para santri tidak muqim di pesantren. Terlebih para alumni dan para pecinta Pondok Pesantren Darullughah Wadda'wah.
\end{abstract}

Kata Kunci: Ta'lim online, Pandemi Covid-19, Darullughah Wadda'wah 


\section{PENDAHULUAN}

Wabah Virus Covid-19 menjadi salahsatu bencana yang menyebar secara cepat di seluruh belahan dunia, khususnya di Indonesia. Pandemi Covid-19 ini berdampak pada berbagai bidang, baik dalam bidang perekonomian, pariwisata dan tentunya berdampak pada pendidikan. ${ }^{1}$ Di masa pandemic ini, pemerintah berupaya untuk kelangsungan proses belajar-mengajar, dengan mempertimbangan situasi dan kondisi. ${ }^{2}$ Berdasarkan keputusan Menteri Pendidikan dan Kebudayaan Republik Indonesia mengenai pendidikan di masa Covid-19, sistem pendidikan yang biasa dilakukan secara tatap muka bergeser menjadi sistem online, ${ }^{3}$ seperti room cloud meeting, whatsapp, google classroom, Quipper dan aplikasi-aplikasi lain yang mendukung proses pembelajaran via online. ${ }^{4} \mathrm{Hal}$ ini tentunya juga berdampak pada Pondok Pesantren sebagai salahsatu lembaga pendidikan yang ada di Indonesia.

Pondok Pesantren sebagai salahsatu lembaga tertua di Indonesia, ${ }^{5}$ juga mengalami hal yang sama. Pondok pesantren lebih dikenal dengan sistem pendidikan yang tradisional. Namun dalam perkembangannya, pesantren mengalami perubahan dari pesantren tradisional menjadi pesantren kekinian. ${ }^{6}$ Pondok Pesantren Darullughah Wadda'wah menjadi salah satu pesantren yang bertransformasi dengan cepat, baik di bidang ekonomi, sarana maupun sistem

${ }^{1}$ Rizqon Halal Syah Aji, "Dampak Covid-19 pada Pendidikan di Indonesia: Sekolah, Keterampilan dan Proses Pembelajaran," SALAM: Jurnal Sosial dan Budaya Syar-i 7, no. 5 (2020): 396.

${ }^{2}$ Hidayatul Muamanah dan Suyadi, "Pelaksanaan Teori Belajar Bermakna David Ausubel Dalam Pembelajaran Pendidikan Agama Islam," Belajea; Jurnal Pendidikan Islam 5, no. 1 (22 Mei 2020): 162 .

${ }^{3}$ Luh Devi Herliandry dkk., "Pembelajaran Pada Masa Pandemi Covid-19," JTP - Jurnal Teknologi Pendidikan 22, no. 1 (30 April 2020): 67, https://doi.org/10.21009/jtp.v22i1.15286; Ali Sadikin dan Afreni Hamidah, "Pembelajaran Daring Di Tengah Wabah Covid-19: (Online Learning in the Middle of the Covid-19 Pandemic)," BIODIK 6, no. 2 (30 Juni 2020): 215, https://doi.org/10.22437/bio.v6i2.9759.

4 Shofiyullahul Kahfi dan Ria Kasanova, "Manajemen Pondok Pesantren Di Masa Pandemi Covid-19 di Pondok Pesantren Mambaul Ulum Kedungadem Bojonegoro," Pendekar: Jurnal Pendidikan Berkarakter 3, no. 1 (April 2020): 26. Wahyu Aji Fatma Dewi, "Dampak Covid19 Terhadap Implementasi Pembelajaran Daring di Sekolah Dasar," Edukatif: Jurnal Ilmu Pendidikan 2, no. 1 (April 2020): 56.

${ }^{5}$ Sri Andri, "Transformasi Pendidikan di Pesantren Pada Abad 21," Tarbawiyab: Jurnal Ilmiah Pendidikan 3, no. 2 (Desember 2019): 147.

${ }^{6}$ Dewi, "Dampak Covid-19 Terhadap Implementasi Pembelajaran Daring di Sekolah Dasar," 79-80. 
pendidikan itu sendiri. ${ }^{7}$ Berdasarkan keputusan Menteri Pendidikan dan Kebudayaan Republik Indonesia, Pondok Pesantren Darullughah Wadda'wah melakukan ta'lim secara online via Dalwa TV. Di masa pandemi Covid-19, Pondok pesantren Darullughah Wadda'wah tidak cukup dengan himbauan stay safe dan stay home. Tetapi stay dars juga disampaikan sebagai salahsatu motivasi para santri Darullughah Wadda'wah agar tetap belajar dalam keadaan apapun.

Artikel ini menjelaskan bagaimana respon Pondok Pesantren Darullughah Wadda'wah atas pandemi Covid-19. Bagaimana persiapan dan model ta'lim di Pondok Pesantren Darullughah Wadda'wah selama pandemi Covid-19. Mengapa lembaga Pondok Pesantren Darullughah Wadda'wah memilih Dalwa Tv sebagai salahsatu sarana untuk melaksanakan ta'lim online. Dua problem akademik tentang respon Pondok Pesantren Darullughah Wadda'wah ini kemudian dikaji dengan Maqashid Syariah.

Mengingat mayoritas masyarakat Indonesia saat ini lebih memilih untuk menerima pengetahuan secara online dibanding melalui ceramah para ustadz atau melalui lembaran-lembaran buku. ${ }^{8}$ Fenomena ta'lim yang dilakukan di Pesantren Darullughah Wadda'wah secara online ini telah dilakukan lima tahun sebelum pandemi Covid-19, melalui media sosial Youtube pada akun Dalwa Tv. Hal ini bertujuan agar para alumni, wali santri dan seluruh masyarakat dari berbagai kalangan dapat mengikuti kajian selama di Pondok Pesantren Darullughah Wadda'wah. Pada awalnya, pengajian ini hanya berupa oase yang disampaikan oleh Dr. Habib Segaf Baharun. Namun seiring dengan menyebarnya virus Covid-19, maka Pondok Pesantren Darullughah Wadda'wah me-launching satelit Dalwa Tv yang dikhususkan untuk santri aktif. Dari sini dapat dilihat bahwa perhatian Pondok Pesantren Darullughah Wadda'wah terhadap santri, alumni maupun wali santri sangat patut diapresiasi.

Sebelumnya, terdapat kajian atas Covid 19 sebagai wabah baru yang penyebarannya begitu cepat, sudah banyak dikaji oleh para sarjana. Pandemi Covid-19 ini tidak hanya berdampak pada bidang ekonomi saja," bidang pendidikan juga turut terdampak pandemi Covid-19. Salahsatunya di dunia

${ }^{7}$ Dian Fauziah, "Sejarah Perkembangan Pondok Pesantren Darullughah Wadda'wah Raci Bangil Pasuruan Tahun 1981-2017”' (Skripsi, Surabaya, UIN Sunan Ampel Surabaya, 2018), $21-22$.

8 Siti Rohmaturrosyidah Ratnawati dan Wilis Werdiningsih, "Pemanfaatan E-Learning Sebagai Inovasi Media Pembelajaran PAI di Era Revolusi Industri 4.0," Belajea; Jurnal Pendidikan Islam 5, no. 2 (30 Desember 2020): 201, https://doi.org/10.29240/belajea.v5i2.1429.

9 Erick Firmansyah, Hangger G. Mawandha, dan M. Prasanto Bimantio, "Pesantren Mandiri Pangan, Program Pelatihan Optimasi Pemanfaatan Lahan Kritis Berbasis Pertanian Terpadu di Pondok Pesantren Al-Himah Gunungkidul," JMM (Jurnal Masyarakat Mandiri) 4, no. 5 (16 November 2020): 797-805, https://doi.org/10.31764/jmm.v4i5.2970. 
pesantren, sebagai salah satu lembaga yang ada di Indonesia. Sebagaimana keputusan Kementrian Pendidikan dan Kebudayaan Republik Indonesia, sistem tatap muka bergeser pada sistem online. ${ }^{10}$ Hal ini memaksa lembaga untuk berinovasi mengenai sistem pembelajaran dengan memanfaatkan media sosial yang ada, diantaranya ialah Pondok Pesantren Darut Taqwa Pasuruan, Pondok Pesantren Sunan Kalijogo Malang, Pondok Pesantren Al-Ghazali Nganjuk dan Pondok Pesantren Miftahul Ula Nganjuk. ${ }^{11}$ Virus Covid-19 yang menyebar dengan cepat, menjadikan pesantren melakukan berbagai upaya untuk mencegah virus tersebut. Salahsatu upaya yang dilakukan pesantren ialah menyediakan tempat cuci tangan ${ }^{12}$ dan membuat bilik disinfektan. ${ }^{13}$

Munculnya virus Covid-19 ini kemudian menjadikan para peneliti untuk melakukan kajian seputar Covid-19 dari berbagai sudut pandang, salahsatunya melalui frame Maqashid Syariah. Dalam mencegah penyebaran virus, Majelis Ulama Indonesia (MUI) mengeluarkan fatwa Nomor 14 Tahun 2020 tentang tata cara penyelenggaraan ibadah di masa pandemi Covid-19. ${ }^{14}$ Selain itu juga tentang kebolehan meninggalkan shalat jumat selama pandemi ini. ${ }^{15} \mathrm{Hal}$ ini tentunya dikaji dengan teori Maqashid Syariah dalam menjawab persoalan yang

10 Shofiyullahul Kahfi dan Ria Kasanova, "Manajemen Pondok Pesantren di Masa Pandemi Covid-19 (Studi Pondok Pesantren Mambaul Ulum Kedungadem Bojonegoro)," Pendekar: Jurnal Pendidikan Berkarakter 3, no. 1 (28 Agustus 2020): 26-30, https://doi.org/10.31764/pendekar.v3i1.2827.

11 Muh Barid Nizarudin Wajdi dkk., "Pendampingan Redesign Pembelajaran Masa Pandemi Covid-19 Bagi Tenaga Pendidik Di Lembaga Pendidikan Berbasis Pesantren Di Jawa Timur," Engagement: Jurnal Pengabdian Kepada Masyarakat 4, no. 1 (31 Mei 2020): 266-77, https://doi.org/10.29062/engagement.v4i1.193.

${ }^{12}$ Dewi Arif Hidayati dkk., "Pendidikan Lingkungan Di Pondok Pesantren Pada Masa Pandemi Covid 19," Prosiding Seminar Nasional Pendidikan Biologi 0, no. 0 (5 September 2020), http://research-report.umm.ac.id/index.php/psnpb/article/view/3656.

${ }^{13}$ Budi Triyono dkk., "Penerapan Automatic Disinfection Chamber Untuk Pencegahan Covid19 Di Pondok Pesantren Al Mujaddadiyah," JATI EMAS (Jurnal Aplikasi Teknik Dan Pengabdian Masyarakat) 4, no. 2 (1 November 2020): 75-78, https://doi.org/10.36339/je.v4i2.310.

14 Hambali Hambali, "Sikap Muslim Terhadap Wabah Covid-19 Dalam Perspektif Maqashid Syari'ah," Journal of Darussalam Islamic Studies 1, no. 1 (30 Oktober 2020): 1-11, https://doi.org/10.47747/jdis.v1i1.86.

15 Ahmad Sanusi, "Teori Maqoshid Syariah Dan Penerpannya Pada Fatwa Korona (Studi Analisis Kritis)," Syakbsia: Jurnal Hukum Perdata Islam 21, no. 1 (11 Agustus 2020): 1-38, https://doi.org/10.37035/syakhsia.v22i1.2914. 
ada di masyarakat dengan melihat pada aspek kemaslahatan, ${ }^{16}$ salahsatunya ialah aspek bif₹ al-nafs. ${ }^{17}$

Selain di bidang keagamaan, bidang pendidikan juga terdampak virus Covid-19. Sistem pembelajaran yang awalnya tatap muka antara guru dan murid, kini bergeser pada sistem online, baik di tingkat Pendidikan Anak Usia Dini (PAUD), ${ }^{18}$ Sekolah Dasar (SD), ${ }^{19}$ Sekolah Menengah Pertama $(\text { SMP })^{20}$ hingga pada tingkat Perguruan Tinggi. ${ }^{21}$ Namun sistem pembelajaran yang dilakukan via online ini dirasa kurang efektif, meskipun motivasi belajar dapat dikatakan sangat baik. ${ }^{22}$ Hal ini kemudian perlu adanya pengembangan dalam sistem pembelajaran online. Salahsatunya tawaran disain pembelajaran (instructional design) guna mendorong kemandirian dan kualitas dalam belajar, diantaranya ADDIE, ASSURE, POE2WE dan ROPES. ${ }^{23}$ Kajian ini berbeda dengan kajian lainnya yang cenderung mengkaji sistem pembelajaran online dalam sudut pandang yang masih umum, seputar teknis dan obyeknya juga terfokus pada lembaga pendidikan di luar Pondok Pesantren. Penelitian ini bertujuan untuk mengetahui bagaimana Tulisan ini menunjukkan bahwa sistem ta'lim di Pondok Pesantren Darullughah Wadda'wah menjadi sebuah tanda perhatian para Masyayikh, para Mu'allim terhadap para santri aktif, alumni dan wali santri di masa Pandemi Covid-19.

16 Sudirman Sudirman dan Muhammad Rusdi Rasyid, "Resolusi Maqasid Syariah Terhadap Penanggulangan Virus Covid-19," Tasamub: Jurnal Studi Islam 12, no. 2 (14 September 2020): 277-94, https://doi.org/10.47945/tasamuh.v12i2.249.

17 Hudzaifah Achmad Qotadah, "Covid-19: Tinjauan Maqasid Al-Shariah Terhadap Penangguhan Pelaksanaan Ibadah Shalat Di Tempat Ibadah (Hifdz al-Nafs Lebih Utama Dari Hifdz al-Din?)," SALAM: Jurnal Sosial Dan Budaya Syar-i 7, no. 7 (25 Mei 2020): 659-72, https://doi.org/10.15408/sjsbs.v7i7.15676.

${ }_{18}$ Nurdin Nurdin dan Laode Anhusadar, "Efektivitas Pembelajaran Online Pendidik PAUD di Tengah Pandemi Covid 19," Jurnal Obsesi : Jurnal Pendidikan Anak Usia Dini 5, no. 1 (10 Agustus 2020): 686-97, https://doi.org/10.31004/obsesi.v5i1.699.

19 Wahyu Aji Fatma Dewi, "Dampak Covid-19 terhadap Implementasi Pembelajaran Daring di Sekolah Dasar," Edukatif: Jurnal Ilmu Pendidikan 2, no. 1 (29 April 2020): 55-61, https://doi.org/10.31004/edukatif.v2i1.89.

${ }^{20}$ Lina Handayani, "Keuntungan, Kendala Dan Solusi Pembelajaran Online Selama Pandemi Covid-19 : Studi Ekploratif Di SMPN 3 Bae Kudus," Journal of Industrial Engineering \& Management Research 1, no. 2 (17 Juli 2020): 15-23, https://doi.org/10.7777/jiemar.v1i2.36.

${ }^{21}$ Firman Firman, "Dampak Covid-19 Terhadap Pembelajaran Di Perguruan Tinggi," BIOMA: Jurnal Biologi Dan Pembelajarannya 2, no. 1 (25 Juni 2020): 14-20.

${ }^{22}$ Yani Fitriyani, Irfan Fauzi, dan Mia Zultrianti Sari, "Motivasi Belajar Mahasiswa Pada Pembelajaran Daring Selama Pandemik Covid-19," Jurnal Kependidikan: Jurnal Hasil Penelitian dan Kajian Kepustakaan di Bidang Pendidikan, Pengajaran dan Pembelajaran 6, no. 2 (4 Juli 2020): 165-75.

${ }^{23}$ Purim Marbun, "Disain Pembelajaran Online Pada Era dan Pasca Covid-19," CSRID (Computer Science Research and Its Development Journal) 12, no. 2 (5 Agustus 2020): 129-42, https://doi.org/10.22303/csrid.12.2.2020.129-142. 
Untuk menjawab permasalahan di atas, tulisan ini menggunakan metode penelitian kualitatif dengan setting studi kasus, yang bertujuan untuk menggambarkan dan menganalisis dan menyimpulkan fenomena ta'lim online di Pondok Pesantren Darullughah Wadda'wah Bangil-Pasuruan selama Pandemi Covid-19. Adapun obyek penelitian ini adalah akun youtube Dalwa Tv, yang mana akun ini merupakan bagian dari beberapa akun resmi Pondok Pesantren Darullughah Wadda'wah Bangil-Pasuruan.

\section{PEMBAHASAN}

\section{Seputar Pondok Pesantren Darullughah Wadda'wah}

Pondok Pesantren Darullughah menjadi salahsatu pesantren yang mengalami transformasi dengan cepat. Baik dalam bidang ekonomi, sarana prasarana maupun dalam bidang pendidikan. ${ }^{24}$ Kajian atas Pondok Pesantren Darullughah Wadda'wah sudah banyak dikaji oleh para sarjana. Pondok Pesantren yang didirikan pada tahun 1981 dengan perkembangan sangat pesat ini tentu didorong oleh beberapa factor pendukung. ${ }^{25}$ Salahsatunya adalah budaya organisasi di Pesantren yang berdampak pada peningkatan mutu pendidikan di Pondok Pesantren. Hal ini berdampak pada kurikulum yang digunakan, yang awalnya terbatas pada kurikulum tradisional bergeser pada kurikulum terpadu. ${ }^{26}$ Namun pondok pesantren tetap menjadikan akhlak sebagai pondasi utama dalam hal apapun. ${ }^{27}$ Tanpa bekal pengetahuan tentang akhlak, manusia akan kehilangan jati dirinya sebagai makhluk yang sempurna. ${ }^{28}$ Pendidikan tasawuf ditanamkan di Pondok Pesantren sebagai salahsatu upaya yang dilakukan lembaga dalam menjaga kepribadian para santri kepada Allah maupun sesama, ${ }^{29}$ salahsatunya tidak memandang struktur sosial. ${ }^{30}$ Tidak hanya

${ }^{24}$ Fauziah, "Sejarah Perkembangan Pondok Pesantren Darullughah Wadda'wah Raci Bangil Pasuruan Tahun 1981-2017," 21-22.

${ }^{25}$ Fauziah, "Sejarah Perkembangan Pondok Pesantren Darullughah Wadda'wah Raci Bangil Pasuruan Tahun 1981-2017.”

26 Uzlifatil Jannah, "Penguatan Budaya Organisasi Dalam Meningkatkan Mutu Pendidikan Pesantren (Studi Kasus di Pondok Pesantren Syaichona Moh. Cholil Bangkalan dan Pondok Pesantren Darullughah Wadda'wah Pasuruan)" (Tesis, Surabaya, Pascasarjana Uin Sunan Ampel Surabaya, 2019).

27 Pasmah Chandra, "Peran Pondok Pesantren Dalam Membentuk Karakter Bangsa Santri Di Era Disrupsi," Belajea; Jurnal Pendidikan Islam 5, no. 2 (30 Desember 2020): 243-62, https://doi.org/10.29240/belajea.v5i2.1497.

28 Atika Fitriani dan Eka Yanuarti, "Upaya Guru Pendidikan Agama Islam Dalam Menumbuhkan Kecerdasan Spiritual Siswa," Belajea; Jurnal Pendidikan Islam 3, no. 2 (31 Desember 2018): 175, https://doi.org/10.29240/belajea.v3i2.527.

${ }^{29}$ Muhammad Idrus, "Implementasi Pendidikan Tasawuf di Pondok Pesantren Dalam Upaya Mencegah Praktek Radikalisme Agama: Studi Multi Situs di Pondok Pesantren Darul 
kental dengan tasawuf, Pondok Pesantren ini juga sangat kental dengan bahasa arab. $^{31}$

Pada awalnya jenjang pendidikan di Madrasah Darullughah Wadda'wah dimulai dari tingkatan I'dadiyah, Madrasah Ibtidaiyah (Ula), Madrasah Ibtidaiyah (Wustho), Madrasah Aliyah (Ulya) sampai program Takhassus. Namun karena zaman yang semakin modern, pada tahun 1992 Habib Hasan Baharun berinisiatif mendirikan pendidikan formal dengan memperoleh izin operasional atau biasa dikenal dengan Program Mu'adalah dengan beberapa tingkatan. Lebih jauh lagi, pada tahun 1995 Pondok Pesantren Darullughah Wadda'wah bergabung dengan Sekolah Tinggi Agama Islam Panca Wahana (STAIPANA) Pasuruan-Jawa Timur. Kemudian Darullughah Wadda'wah mendapat izin operasional Institut Agama Islam Darullughah Wadda'wah pada tahun 1997. ${ }^{32}$ Lembaga pendidikan di Pondok Pesantren Darullughah Wadda'wah dapat dikategorikan pada 3 bagian. Pertama, Pendidikan Diniyah/Pondok yang terdiri dari I'dadiyah, Madrasah Ibtidaiyah (Ula), Madrasah Tsanawiyah (Wustho), Madrasah Aliyah (Ulya), Program Takhasus dan Kursus. Kedua, Kurikulum Depag/Diknas yang terdiri dari Madrasah Ibtidaiyah DALWA, Madrasah Tsanawiyah DALWA dan Madrasah Aliyah DALWA. Ketiga, Perguruan Tinggi yang terdiri dari Strata 1, Strata 2 dan Strata $3 .^{33}$

Pesantren Darullughah Wadda'wah merupakan salahsatu pesantren yang ada di Jawa Timur, tepatnya di Desa Raci, Kecamatan Bangil-Pasuruan. Pondok pesantren ini didirikan pada tahun 1981 oleh Al-Habib Hasan bin Ahmad Baharun. Pada awalnya, Abuya Hasan bin Ahmad Baharun menerima 6 santri yang bertempat di kontrakan sebagai tempat mengaji. Hal ini tentunya mengakibatkan lokasi berpindah-pindah. Dari tahun 1981 sampai 1984, pesantren ini telah tercatat sebanyak 13 kali mengalami perpindahan. Kemudian pada tahun 1985, didirikan bangunan pesantren pusat di Desa Raci, Bangil. Pondok pesantren ini didirikan untuk mencetak kader yang melek intelektual dan teknologi. Hal ini sebagaimana yang tertulis dalam visi dan misi Pesantren Darullughah Wadda'wah. Tidak lebih dari 35 tahun, Pondok Pesantren

Ihya' li Ulumiddin Bangil dan Pondok Pesantren Darullughah Waddawa'wah Bangil Kab. Pasuruan" (Tesis, Malang, Sekolah Pascasarjana Uin Maulana Malik Ibrahim Malang, 2019).

${ }^{30}$ Dewi Masita, "Pesantren Darul Lugho Wa Dakwa (DALWA) dan Struktur Sosial di

Era Globalisasi: Studi Analisis Sosiologi Pendidikan Dalwa Bangil Pasuruan," Al-Ibrah 1, no. 2 (Desember 2016).

31 Anuarsyah, "Strategi Pembentukan Lingkungan Berbahasa Arab dalam Perspektif Behaviorisme” (Tesis, Malang, Sekolah Pascasarjana Uin Maulana Malik Ibrahim Malang, 2017).

32 Fauziah, "Sejarah Perkembangan Pondok Pesantren Darullughah Wadda'wah Raci Bangil Pasuruan Tahun 1981-2017," 42.

33 "Pondok Pesantren Darullughah Wadda'wah," diakses 23 November 2020, http://ppdalwa.org/id/index.php?prm=ponpes\&id=1. 
Darullughah Wadda'wah ini telah berkembang pesat, baik dari segi sarana prasaran, sistem pembelajaran maupun jumlah santri yang semakin meningkat. Pada tahun 1983, Pondok Pesantren Darullughah Wadda'wah menerima 16 santriwati. Pada tahun berikutnya, jumlah santri semakin bertambah sehingga ada 13 rumah kontrakan yang ditempati para santri. Atas petunjuk Sayyid Muhammad Alwi Al-Maliki selaku Musyrif, Pondok Pesantren Darullughah Wadda'wah dipindah ke Desa Raci dengan sarana prasarana yang cukup memadai. Pondok Pesantren Darullughah Wadda'wah telah memiliki sebanyak 3 cabang, yakni Darullughah Wadda'wah 2, Darullughah Wadda'wah 3 di Desa Belawi Bangil dan Pondok Putri yang ada di Desa Raci. ${ }^{34}$

\section{Model Ta'lim Online dan Persiapannya}

Di masa pandemi Covid-19 ini, ta'lim online dilakukan oleh beberapa Pondok Pesantren di Indonesia, salahsatunya Pondok Pesantren Darullughah Wadda'wah Bangil. Dalam melaksanakan ta'lim online ini, Pondok Pesantren menggunakan Dalwa Tv. Tentunya ta'lim online ini dibutuhkan persiapan yang matang guna pelaksanaan berjalan secara maksimal. Sehingga diperlukan adanya evaluasi proses belajar mengajar. Dalam mengevaluasi sistem pembelajaran, tentunya asatidz menjadi pelaksana utama dalam memperbaiki proses belajarmengajar. Hal ini tidak lain karena asatidz mengetahui hal-hal yang ada dalam proses belajar-mengajar. ${ }^{35}$ Ada beberapa persiapan yang dilakukan oleh keluarga besar Pondok Pesantren sebelum melaksanakan ta'lim online. Pertama, pendistribusian parabola Dalwa Tv. Kedua, pembentukan jadwal ta'lim. Ketiga, pembuatan absensi online. Keempat, terkait kesiapan para mu'allim dalam melaksanakan $t a^{\prime} l i m$ online.

Ta'lim online yang ada di Pondok Pesantren Darullughah Wadda'wah ini dilakukan sebagaimana pembelajaran pada umumnya. Secara umum, ta'lim online dilaksanakan pada hari Sabtu sampai Kami, yang dimulai dari jam 06:0019:30. Para santri menyimak dan mencatat materi yang disampaikan oleh mu'allim sesuai dengan jadwal dan kelas masing-masing, mulai dari tingkat Ibtidaiyah, Tsanawiyah hingga tingkat Aliyyah. Pada tingkat Ibtidaiyyah, materi mulai dari tingkat Ibtidaiyah, Tsanawiyah hingga tingkat Aliyyah. Pada tingkat Ibtidaiyyah, materi yang disampaikan seputar Nahwu, Shorof, Al-Qur'an, Hadis, Fiqh, Siroh, Akblaq, Arabiyah, Muhawarah dan juga materi Imla. Sedangkan

34 Idrus, "Implementasi Pendidikan Tasawuf di Pondok Pesantren Dalam Upaya Mencegah Praktek Radikalisme Agama: Studi Multi Situs di Pondok Pesantren Darul Ihya' li Ulumiddin Bangil dan Pondok Pesantren Darullughah Waddawa'wah Bangil Kab. Pasuruan," 95-96.

${ }^{35}$ Siswanto Siswanto dan Eli Susanti, "Evaluasi Program Pendidikan Islam," Paramurobi: Jurnal Pendidikan Agama Islam 2, no. 1 (5 Oktober 2019): 66, https://doi.org/10.32699/paramurobi.v2i1.817. 
materi yang disampaikan pada tingkat Tsanawiyah tidak jauh berbeda dengan kelas Ibtidaiyah, hanya saja pada kelas Tsanawiyah berupa materi lanjutan dari kelas sebelumnya seperti materi Ushul Figh, Tafsir dan Balaghah. Begitu juga dengan materi pada tingkat Aliyyah, materi yang disampaikan lebih luas cakupannya seperti Figh Muamalah, Fiqh Nikah, Fiqh Qadho', Figh Jihad, Fiqh Tahawulat, Tafsir Abkam, Mustholah dan juga Qawa'id.

Selain ta'lim yang dikhususkan untuk para santri aktif, Pondok Pesantren Darullughah Wadda'wah juga memfasilitasi para alumni, wali santri dan para pecinta Pondok Pesantren Darullughah Wadda'wah dengan menayangkan pengajian secara aktif. Ta'lim online ini ditayangkan melalui Youtube Dalwa TV dengan berbagai tema dan disampaikan secara langsung oleh para Habib dan Ustadz di Pondok Pesnatren Darullughah Wadda'wah. Secara umum, ta'lim online lebih banyak disampaikan oleh Al-Habib Segaf Baharun sebagai salahsatu mu'allim yang paling banyak viewers dan juga jam tayangnya.

Tema-tema yang disampaikan oleh Al-Habib Segaf Baharun dalam ta'lim online sangatlah beragam. Seperti "Kemuliaan Sifat Dermawan", "Kemuliaan Sifat Sabar", "Bahaya Lisan", "Larangan Ghibah dan Bahayanya", "Seputar Hukum Berbohong dan Bahayanya", "Aktifitas Tarwiyah dan Problematikanya dalam Rangkaian Haji", "Seputar Doa dan Syarat Agar Doa Terkebaul", "Menempatkan Orang Lain Sesuai dengan Tempatnya", "Dialog Interaktif Seputar Syari'at Islam", "Talkshow Dalwa Part 1-2", "Panduan Berinteraksi Dalam Kehidupan Sosial" dan tema-tema yang lain. Tema-tema tersebut dapat dikategorikan pada 3 bidang yakni Muamalah, Akhlak dan Ibadah. Dari tiga bidang tersebut, tema muamalah sebanyak 13\%, akhlak 23\% dan bidang ibadah sebanyak $64 \%$. Tema yang paling banyak diminati oleh viewvers adalah persoalan ibadah. Hal ini tidak lain karena tema yang paling banyak disampaikan oleh AlHabib Segaf Baharun dalam ta'lim online adalah kajian seputar ibadah dibandingkan tema yang lainnya.

Pondok Pesantren Darullughah Wadda'wah memiliki peran yang sangat penting dalam pembelajaran online via Dalwa Tv. Hal ini sebagaimana yang diungkapkan oleh santri, wali santri dan juga alumni dalam kegiatan "Talk Show Dalwa Menjalankan 2 Misi Penting di Masa Pandemi Bersama Ulama” yang diadakan Pondok Pesantren Darullughah Wadda'wah dengan mengundang langsung perwakilan maupun melalui telewicara. Selain itu, salahsatu mu'allim dan kru Dalwa Tv Pondok Pesantren Darullughah Wadda'wah yang bertugas mengungkapkan bahwa kegiatan distributor satelit Dalwa Tv mengalami sedikit kewalahan, dikarenakan pesanan yang sangat banyak.

Pemilihan Dalwa Tv sebagai sarana ta'lim online di masa Pandemi Covid-19 merupakan sebuah keputusan yang tepat. Hal ini sebagaimana yang 
disampaikan oleh Ustadz Ismail Ayyub sebagai Kepala Departemen Kesiswaan Pondok Pesantren Darullughah Wadda'wah, pertama, factor harga. Persoalan harga pemasangan satelit Dalwa Tv tidak menjadi masalah karena harga yang dipatok sudah mendapat subsidi dari Pondok Pesantren Darullughah Wadda'wah. Selain itu, satelit Dalwa Tv ini bebas biaya bulanan dan tanpa koneksi jaringan internet. Kedua, factor manfaat. Pondok Pesantren Darullughah Wadda'wah tidak memilih parabola umum, hal ini tidak lain karena tayangannya terlalu umum yang dirasa kurang cocok untuk santri. Sehingga perlu adanya satelit khusus yang berisi tayangan-tayangan yang Islami.

\section{Misi Penting Pondok Darullughah Wadda'wah di Era Pandemi Covid-19}

Pandemi Covid-19 telah merubah sistem pembelajaran di seluruh penjuru Indonesia. Berdasarkan keputusan Kementrian Pendidikan dan Budaya dalam rangka memutus rantai virus Covid-19, sistem pembelajaran yang awalnya luring atau tatap muka menjadi daring atau online. Pondok Pesantren Darullughah Wadda'wah sebagai salahsatu lembaga pendidikan yang ada di Indonesia juga melaksanakan pembelajaran secara online via Dalwa Tv. Pondok Pesantren Darullughah Wadda'wah menjalankan 2 misi penting di masa Pandemi Covid19.

Pertama, Geliat da'wah dan pendidikan online dalam menyebarkan ilmu Rasulullah saw. di era Pandemi. Meskipun para santri tidak berada di Pesantren, maka pihak Pondok Pesantren mengupayakan agar para santri tetap mendapat asupan keilmuan sebagaimana di Pondok Pesantren. Hal ini dilakukan oleh Pondok Pesantren Darullughah Wadda'wah melalui Dalwa Tv, sebagai salahsatu saran menyampaikan pengetahuan dan informasi yang ada. Namun tidak hanya seputar keilmuan saja, kegiatan sehari-hari yang biasa dilakukan di Pondok Pesantren Daruluughah Wadda'wah seperti riyadhah dan ubudiyyah juga ditayangkan dalam Dalwa Tv.

Kedua, menguak hikmah syari'at Islam dibalik protocol kesehatan di masa Pandemi Covid-19. Di masa Pandemi Covid-19, pemerintah menghimbau masyarakat agar di rumah saja dan selalu mematuhi protokol kesehatan. Ketaatan terhadap pemerintah ini menjadi salahsatu usaha mentaati agama, Rasul dan Allah. Dalam kondisi yang seperti ini, maka kita dianjurkan untuk mentaati para tenaga medis agar terhindar dari wabah. Rasulullah saw. juga menganjurkan umatnya tidak keluar rumah ketika ada suatu wabah. Hal ini sebagaimana dalam Musnad Ahmad bin Hanbal Bab Baaqi al-Musnad al-Sabiq, no. 24943 yang diriwayatkan oleh 'Aisyah: ${ }^{36}$

${ }^{36}$ Gawami AlKalem V4.5, t.t. 


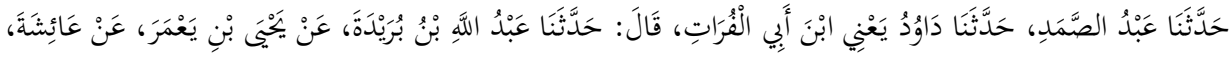

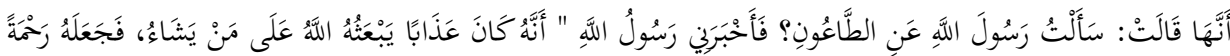

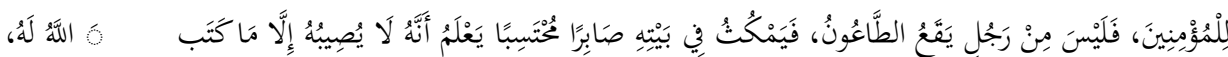

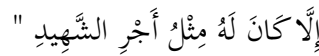

Artinya: Telah menceritakan kepada kami, Abdusshomad telah menceritakan kepada kami Daud, yaitu Ibn Abu Al Furat dia berkata: Telah menceritakan kepada kami Abdullah bin Buraidah dari Yahya bin Ya'mar dari Aisyah, babwa dia berkata, "Saya bertanya kepada Rasulullah mengenai penyakit tha'un. Kemudian Rasulullah mengabarkan kepadaku bahwa ia adalah adzab yang Allah kirim bagi siapa yang Ia kehendaki, dan Ia menjadikannya sebagai rahmat bagi orang-orang beriman. Tidaklah seseorang yang berada di wilayah yang terjangkit penyakit tha'un, kemudian ia tetap tinggal di rumahnya, sabar dan mengharap pabala Allah, ia mengetabui bahwa ia tidak akan menjangkitinya kecuali apa yang telah Allah tetapkan kepadanya, kecuali baginya seperti pabalanya orang yang mati syahid."

Transformasi keilmuan yang dilakukan oleh Pondok Pesantren Darullughah Wadda'wah merupakan sebuah kegiatan yang patut dicontoh oleh lembaga pendidikan yang lain, khususnya lembaga pendidikan yang ada di lingkungan Pondok Pesantren. Seiring dengan teknologi yang semakin berkembang, maka Pondok Pesantren Darullughah melakukan terobosan baru melalui Dalwa Tv. Dengan adanya Dalwa Tv ini bukan untuk bersaing dalam teknologi, namun untuk mensuplai faedah dan kalam rohani untuk para santri aktif, para alumni, wali santri dan juga para pecinta Darullugah Wadda'wah dapat memperoleh pengetahuan sebagaimana di Pondok Pesantren.

\section{KESIMPULAN}

Sebagai kata penutup, pendidikan menjadi persoalan yang penting sampai saat ini menjadikan para pendidik selalu semangat untuk berinovasi dalam proses belajar-mengajar. Pandemi Covid-19 menjadi salahsatu factor pendorong para pendidik untuk menginovasi pembelajaran tanpa tatap muka. Pembelajaran secara online menjadi solusi bersama agar proses belajar-mengajar tetap berlangsung. Pondok Pesantren Darullughah Wadda'wah menjadi salahsatu lembaga dalam lingkup Pondok Pesantren yang melakukan terobosan baru melalui Dalwa TV. Namun kajian ini terbatas pada respon Pondok Pesantren Darullughah Wadda'wah atas pandemic Covid-19 dan bagaimana pembelajaran yang dilakukan selama pandemic Covid-19. Berangkat dari kajian ini kemudian perlu kiranya dilakukan penelitian lebih lanjut seputar keberkahan dan juga sanad keilmuan pada pembelajaran atau ta’lim online. 


\section{BIBLIOGRAPHY}

Aji, Rizqon Halal Syah. "Dampak Covid-19 pada Pendidikan di Indonesia: Sekolah, Keterampilan dan Proses Pembelajaran." SALAM: Jurnal Sosial dan Budaya Syar-i 7, no. 5 (2020).

Andri, Sri. "Transformasi Pendidikan di Pesantren Pada Abad 21." Tarbawiyah: Jurnal Ilmiah Pendidikan 3, no. 2 (Desember 2019).

Anuarsyah. "Strategi Pembentukan Lingkungan Berbahasa Arab dalam Perspektif Behaviorisme.” Tesis, Sekolah Pascasarjana Uin Maulana Malik Ibrahim Malang, 2017.

Chandra, Pasmah. "Peran Pondok Pesantren Dalam Membentuk Karakter Bangsa Santri Di Era Disrupsi." Belajea; Jurnal Pendidikan Islam 5, no. 2 (30 Desember 2020): 243-62. https://doi.org/10.29240/belajea.v5i2.1497.

Dewi, Wahyu Aji Fatma. "Dampak Covid-19 Terhadap Implementasi Pembelajaran Daring di Sekolah Dasar." Edukatif: Jurnal Ilmu Pendidikan 2, no. 1 (April 2020).

- "Dampak COVID-19 terhadap Implementasi Pembelajaran Daring di Sekolah Dasar." Edukatif: Jurnal Ilmu Pendidikan 2, no. 1 (29 April 2020): 55-61. https://doi.org/10.31004/edukatif.v2i1.89.

Fauziah, Dian. "Sejarah Perkembangan Pondok Pesantren Darullughah Wadda'wah Raci Bangil Pasuruan Tahun 1981-2017.” Skripsi, UIN Sunan Ampel Surabaya, 2018.

Firman, Firman. "Dampak Covid-19 Terhadap Pembelajaran Di Perguruan Tinggi.” BIOMA: Jurnal Biologi Dan Pembelajarannya 2, no. 1 (25 Juni 2020): 14-20.

Firmansyah, Erick, Hangger G. Mawandha, dan M. Prasanto Bimantio. "Pesantren Mandiri Pangan, Program Pelatihan Optimasi Pemanfaatan Lahan Kritis Berbasis Pertanian Terpadu Di Pondok Pesantren AlHikmah Gunungkidul." JMM (Jurnal Masyarakat Mandiri) 4, no. 5 (16 November 2020): 797-805. https://doi.org/10.31764/jmm.v4i5.2970.

Fitriani, Atika, dan Eka Yanuarti. "Upaya Guru Pendidikan Agama Islam Dalam Menumbuhkan Kecerdasan Spiritual Siswa." Belajea; Jurnal Pendidikan Islam 3, no. 2 (31 Desember 2018): 173-202. https://doi.org/10.29240/belajea.v3i2.527.

Fitriyani, Yani, Irfan Fauzi, dan Mia Zultrianti Sari. "Motivasi Belajar Mahasiswa Pada Pembelajaran Daring Selama Pandemik Covid-19." Jurnal

Kependidikan: Jurnal Hasil Penelitian dan Kajian Kepustakaan di Bidang

Pendidikan, Pengajaran dan Pembelajaran 6, no. 2 (4 Juli 2020): 165-75.

Gawami AlKalem V4.5, t.t. 
Hambali, Hambali. "Sikap Muslim Terhadap Wabah Covid-19 Dalam Perspektif Maqashid Syari'ah." Journal of Darussalam Islamic Studies 1, no. 1 (30 Oktober 2020): 1-11. https://doi.org/10.47747/jdis.v1i1.86.

Handayani, Lina. "Keuntungan, Kendala Dan Solusi Pembelajaran Online Selama Pandemi Covid-19: Studi Ekploratif Di SMPN 3 Bae Kudus." Journal of Industrial Engineering \& Management Research 1, no. 2 (17 Juli 2020): 15-23. https://doi.org/10.7777/jiemar.v1i2.36.

Herliandry, Luh Devi, Nurhasanah Nurhasanah, Maria Enjelina Suban, dan Heru Kuswanto. "Pembelajaran Pada Masa Pandemi Covid-19." JTP . Jurnal Teknologi Pendidikan 22, no. 1 (30 April 2020): 65-70. https://doi.org/10.21009/jtp.v22i1.15286.

Hidayati, Dewi Arif, H. Husamah, Diani Fatmawati, Fuad Jaya Miharja, dan Ahmad Fauzi. "Pendidikan Lingkungan Di Pondok Pesantren Pada Masa Pandemi Covid 19." Prosiding Seminar Nasional Pendidikan Biologi 0, no. 0 (5 September 2020). http://researchreport.umm.ac.id/index.php/psnpb/article/view/3656.

Idrus, Muhammad. "Implementasi Pendidikan Tasawuf di Pondok Pesantren Dalam Upaya Mencegah Praktek Radikalisme Agama: Studi Multi Situs di Pondok Pesantren Darul Ihya' li Ulumiddin Bangil dan Pondok Pesantren Darullughah Waddawa'wah Bangil Kab. Pasuruan.” Tesis, Sekolah Pascasarjana Uin Maulana Malik Ibrahim Malang, 2019.

Jannah, Uzlifatil. "Penguatan Budaya Organisasi Dalam Meningkatkan Mutu Pendidikan Pesantren (Studi Kasus di Pondok Pesantren Syaichona Moh. Cholil Bangkalan dan Pondok Pesantren Darullughah Wadda'wah Pasuruan)." Tesis, Pascasarjana Uin Sunan Ampel Surabaya, 2019.

Kahfi, Shofiyullahul, dan Ria Kasanova. "MANAJEMEN PONDOK PESANTREN DI MASA PANDEMI COVID-19 (Studi Pondok Pesantren Mambaul Ulum Kedungadem Bojonegoro)." Pendekar: Jurnal Pendidikan Berkarakter 3, no. 1 (28 Agustus 2020): 26-30. https://doi.org/10.31764/pendekar.v3i1.2827.

Marbun, Purim. "Disain Pembelajaran Online Pada Era Dan Pasca Covid-19." CSRID (Computer Science Research and Its Development Journal) 12, no. 2 (5 Agustus 2020): 129-42. https://doi.org/10.22303/csrid.12.2.2020.129142.

Masita, Dewi. "Pesantren Darul Lugho Wa Dakwa (DALWA) dan Struktur Sosial di Era Globalisasi: Studi Analisis Sosiologi Pendidikan Dalwa Bangil Pasuruan." Al-Ibrah 1, no. 2 (Desember 2016).

Muamanah, Hidayatul, dan Suyadi. "Pelaksanaan Teori Belajar Bermakna David Ausubel Dalam Pembelajaran Pendidikan Agama Islam." Belajea; Jurnal Pendidikan Islam 5, no. 1 (22 Mei 2020): 161-80. 
Nurdin, Nurdin, dan Laode Anhusadar. "Efektivitas Pembelajaran Online Pendidik PAUD di Tengah Pandemi Covid 19." Jurnal Obsesi: Jumal Pendidikan Anak Usia Dini 5, no. 1 (10 Agustus 2020): 686-97. https://doi.org/10.31004/obsesi.v5i1.699.

"Pondok Pesantren Darullughah Wadda'wah." Diakses 23 November 2020. http://pp-dalwa.org/id/index.php?prm=ponpes\&id=1.

Qotadah, Hudzaifah Achmad. "Covid-19: Tinjauan Maqasid Al-Shariah Terhadap Penangguhan Pelaksanaan Ibadah Shalat Di Tempat Ibadah (Hifdz al-Nafs Lebih Utama Dari Hifdz al-Din?)." SALAM: Jurnal Sosial Dan Budaya Syar-i 7, no. 7 (25 Mei 2020): 659-72. https://doi.org/10.15408/sjsbs.v7i7.15676.

Ratnawati, Siti Rohmaturrosyidah, dan Wilis Werdiningsih. "Pemanfaatan ELearning Sebagai Inovasi Media Pembelajaran PAI di Era Revolusi Industri 4.0." Belajea; Jurnal Pendidikan Islam 5, no. 2 (30 Desember 2020): 199-220. https://doi.org/10.29240/belajea.v5i2.1429.

Ria Kasanova, Shofiyullahul Kahfi dan. "Manajemen Pondok Pesantren Di Masa Pandemi Covid-19 di Pondok Pesantren Mambaul Ulum Kedungadem Bojonegoro." Pendekar: Jurnal Pendidikan Berkarakter 3, no. 1 (April 2020).

Sadikin, Ali, dan Afreni Hamidah. "Pembelajaran Daring Di Tengah Wabah Covid-19: (Online Learning in the Middle of the Covid-19 Pandemic)." BIODIK 6, no. 2 (30 Juni 2020): 214-24. https://doi.org/10.22437/bio.v6i2.9759.

Sanusi, Ahmad. "Teori Maqoshid Syariah Dan Penerpannya Pada Fatwa Korona (Studi Analisis Kritis)." Syakhsia: Jurnal Hukum Perdata Islam 21, no. 1 (11 Agustus 2020): 1-38. https://doi.org/10.37035/syakhsia.v22i1.2914.

Siswanto, Siswanto, dan Eli Susanti. "EVALUASI PROGRAM PENDIDIKAN ISLAM." PARAMUROBI: JURNAL PENDIDIKAN AGAMA ISLAM 2, no. 1 (5 Oktober 2019): 65-74. https://doi.org/10.32699/paramurobi.v2i1.817.

Sudirman, Sudirman, dan Muhammad Rusdi Rasyid. "Resolusi Maqasid Syariah Terhadap Penanggulangan Virus Covid-19." TASAMUH: Jurnal Studi Islam 12, no. 2 (14 September 2020): 277-94. https://doi.org/10.47945/tasamuh.v12i2.249.

Triyono, Budi, Yuli Prasetyo, Hanifah Nur Kumala Ningrum, Raden Jasa Kusumo Haryo, Basuki Winarno, dan Aldanur I. R. "Penerapan Automatic Disinfection Chamber Untuk Pencegahan Covid19 Di Pondok Pesantren Al Mujaddadiyah." JATI EMAS (Jurnal Aplikasi Teknik Dan Pengabdian Masyarakat) 4, no. 2 (1 November 2020): 75-78. https://doi.org/10.36339/je.v4i2.310. 
Wajdi, Muh Barid Nizarudin, M. Burhanuddin Ubaidillah, Sri Mulyani, Khoirul Anwar, Lailatul Istiqomah, Fauziyah Rahmawati, Sholihatul Atik Hikmawati, Diah Retno Ningsih, dan Hasan Syaiful Rizal. "Pendampingan Redesign Pembelajaran Masa Pandemi Covid-19 Bagi Tenaga Pendidik Di Lembaga Pendidikan Berbasis Pesantren Di Jawa Timur.” Engagement: Jurnal Pengabdian Kepada Masyarakat 4, no. 1 (31 Mei 2020): 266-77. https://doi.org/10.29062/engagement.v4i1.193. 
54 | Belajea: Jurnal Pendidikan Islam, Vol. 6, No. 1, 2021 